\title{
ANALISIS PREFERENSI KONSUMEN TERHADAP KECAP CAP IKAN TERBANG PT. SURYA MANDALA DI PASAR ANOM KECAMTAN KOTA SUMENEP
}

\section{Consumer Preference Analysis Of Soy Sauce Cap Ikan Terbang Pt. Surya Mandala In The Anom Market Of Sumenep District}

\author{
Rifatul Wahdah ${ }^{1 * *}$, Isdiantoni ${ }^{2)}$, Purwati Ratna Wahyuni ${ }^{3)}$ \\ ${ }^{1,2,3)}$ Prodi Agribisnis, Universitas Wiraraja \\ Jalan Raya Sumenep-Pamekasan km 05 Patean, Sumenep \\ rifatulwahdah190696@gmail.com
}

\begin{abstract}
The soy sauce products marketed at Anom Regency Market consist of local and national soy sauce brands. Cap Ikan Terbang is a local soy sauce so it needs a distinctive differentiator to be able to compete in the market. The differentiator is intended as an effort to meet the needs of consumers. So that the product can compete then know the desires of consumers against soy sauce. This research is to find out the variable Kecap Cap Ikan Terbang as the consumer's preference in the Anom Market in Sumenep City Subdistrict, to examine the significant relationship between the variables of Taste, Packaging, Place, Price, and Resilience with consumers' preferences in buying Flying Fish soy sauce in Anom Market, Sumenep City District. The determination of the research area was carried out deliberately (purposive), namely Arif Shop in Anom Market, Sumenep Regency with consideration because it is one of the shops that sell cap Ikan Terbang soy sauce and has a permanent consumer of Flying Fish soy sauce. The results showed that the variables most preferred by consumers were taste and price followed by packaging, place and durability. Chi-square test results show that the calculated X2 value is greater than X2 table which is 29.11>3.481 which means $\mathrm{HO}$ is rejected $\mathrm{Ha}$ is accepted, which means there is a relationship between consumer preferences for all Cap Ikan Terbang soy sauce variable variables in the Anom Market, and the results of the contingency coefficient test indicate the value of $0.59 \neq 0$, which means there is a significant relationship between consumer preferences for all Flying Fish soy sauce variables. The final Likert scale test results showed a value of $88.6 \%$ which means it is in the category of Very Like.
\end{abstract}

Keywords: Cap ikan terbang, consumers, preferences, soy sauce.

\begin{abstract}
Abstrak
Produk kecap yang dipasarkan di Pasar Anom Kabupaten terdiri dari merk kecap lokal dan nasional. Ikan Terbang merupakan kecap lokal sehingga perlu adanya pembeda khas untuk dapat bersaing di pasaran. Pembeda yang dimaksud sebagai upaya untuk memnuhi kebutuhan konsumen. Agar produk dapat bersaing maka mengetahui keinginan konsumen terhadap kecap. Tujuan Penelititan untuk mengetahui variabel kecap cap Ikan Terbang yang menjadi preferensi konsumen di Pasar Anom Kecamatan Kota Sumenep, mengkaji hubungan yang signifikan antara variabel Rasa, Kemasan, Tempat, Harga, Ketahanan dengan kesukaan konsumen dalam membeli kecap cap Ikan Terbang di Pasar Anom Kecamatan Kota Sumenep. Penentuan daerah penelitian dilakukan secara sengaja (purposive) yaitu Toko Arif di Pasar Anom Kabupaten Sumenep dengan pertimbangan karena merupakan salah satu toko yang menjual kecap cap Ikan Terbang dan memiliki konsumen tetap kecap
\end{abstract}


cap Ikan Terbang. Hasil penelitian menunjukkan bahwa variabel yang paling disukai oleh konsumen adalah rasa dan harga diikuti oleh variabel kemasan, tempat dan ketahanan. Hasil uji chi-square menunjukkan bahwa nilai $X^{2}$ hitung lebih besar daripada $X^{2}$ tabel yaitu $29,11>3,481$ yang berarti $\mathrm{H}_{0}$ ditolah Ha diterima yang artinya ada hubungan antara kesukaan konsumen terhadap semua variabel kecap cap Ikan Terbang di Pasar Anom, dan hasil uji koefisien kontingensi menunjukkan nilai sebesar $0,59 \neq 0$ yang artinya ada hubungan yang signifikan antara kesukaan konsumen terhadap semua variabel kecap cap Ikan Terbang. Hasil uji skala likert akhir menunjukkan nilai 88,6\% yang artinya berada dalam ketegori Sangat Suka.

Kata Kunci : cap ikan terbang, kecap, konsumen, preferensi.

\section{PENDAHULUAN}

Pengembangan industri pengolahan pangan di Indonesia yang di dukung oleh sumberdaya alam pertanian, baik nabati maupun hewani yang mampu menghasilkan berbagai produk olahan yang dapat dibuat dan dikembangkan dari sumber daya alam lokal atau daerah. Di Indonesia banyak terdapat industri pengolahan hasil pertanian, salah satunya adalah industri pengolahan kedelai menjadi kecap.

Industri kecap merupakan salah satu bidang usaha yang melakukan aktifitas usaha bidang industri pertanian (agroindustri). Produksi kecap merupakan kegiatan produksi yang memanfaatkan hasil pertanian berupa kedelai yang merupakan bahan baku utama pada proses pengolahan saus kecap kental dengan ciri khas berwarna hitam. Dalam sistem agribisnis, industri kecap termasuk subsistem hilir pada aktivitas agribisnis dimana telah memproses dan mentransformasikan bahan baku yang berupa hasil pertanian (kedelai) menjadi produk pangan yang siap konsumsi.

Salah satu industri skala rumah tangga di Kabupaten Sumenep adalah perusahaan kecap cap Ikan Terbang yang terletak di Desa Mandala, Kecamatan Gapura perusahaan ini memproduksi kecap dari bahan baku kedelai. Kecap yang di hasilkan memiliki rasa dan aroma kedelai asli dan mutunya tetap terjaga. Perusahaan kecap Cap Ikan Terang awalnya memproduksi kecap dengan kemampuan berproduksi yang sedikit lemah dan tenaga kerja yang relatif sedikit, tetapi perusahaan ini dengan tekun mengembangkan bidang usahanya sehingga kecap cap Ikan Terbang mulai di kenal oleh masyarakat luas dan berhasil memasuki pasaran Kabupaten Sumenep.

Produk kecap yang ada dan dipasarkan di Pasar tradisional (Anom) Kabupaten Sumenep sangat beragam mulai dari merek nasional maupun merek lokal. Produk kecap yang ada di Pasar Anom dapat terlihat di warung maupun toko sembako yang menjual berbagai merek kecap selain merek Ikan Terbang. Salah satu contoh merek kecap lokal yang dijual yaitu kecap cap Dua Kelapa. Produk kecap nasional yang dipasarkan di pasar Anom Sumenep diantaranya kecap Bango, ABC, Sedap, Indofood, dan lainnya.

Pasar Anom merupakan pasar tradisional Kota Sumenep yang menjadi pusat pembelajaan tradisional terbesar di Kabupaten Sumenep. Umumnya kondisi pasar tradisional dikenal dengan kesan kotor dan bau, becek bahkan tidak aman. Berdasarkan harga, pasar tradisional juga dikenal dengan patokan harga produk yang tidak pasti karena mempraktikkan adu tawar. Produk yang dijual di pasar tradional juga dinilai kurang lengkap kaarena lebih banyak menjual produk yang tidak awet dan merupakan produk lokal. Bebera faktor yang memberikan kesan kurang baik pada pasar tradisional tersebut akhirnya mengakibatkan pasar tradisional 
mulai kehilangan pembeli. Selain dari kesan yang kurang baik pada pasar tradisional, namun pasar tradional tetap berdiri hingga saat ini karena memiliki keunggulan, berupa keakraban diantar penjual dan pembeli karena saling berinteraksi dan berkomunikasi sehingga hal tersebut menimbulkan hubungan sosial antara penjual dan pembeli secara baik (Wardana, 2013).

Beragamnya ketersediaan merek kecap di Pasar Anom Kabupaten Sumenep membuat kecap cap Ikan Terbang PT. Surya Mandala perlu membangun keunggulan diantara produk lain misalnya dengan menciptakan keunikan bagi produk kecap, mencari tahu, menganalisis dan berupaya memenuhi kebutuhan kecap sebagaimana permintaan konsumen. Memiliki keunikan serta mengetahui keinginan konsumen dimaksudkan sebagai upaya membangun brand pembeda dengan produk saingan yang ada di pasaran serta untuk menciptakan daya tarik pada konsumen agar terbangun loyalitas konsumen bagi perusahaan. Keunikan atau pembeda produk kecap dapat diaplikasikan pada atribut produk kecap misalnya rasa, aroma, warna maupun desain atau volume kecap per kemasan atau harga produk kecap sendiri. Penelitian bertujuan untuk mengetahui variabel kecap cap Ikan Terbang yang menjadi preferensi konsumen serta mengkaji hubungan yang signifikan antara variabel (Rasa, Merk, Kemasan, Tempat, Harga, Ketahanan) dengan kesukaan konsumen dalam membeli kecap cap Ikan Terbang di Pasar Anom Kecamatan Kota Sumenep.

\section{METODE PENELITIAN}

Metode penelitian yaitu kuantitatif dan metode kualitatif. Metode kuantitatif adalah suatu metode dengan cara mengumpulkan data dalam bentuk angka- angka. Metode kualitatif adalah metode penelitian yang digunakan untuk meneliti pada objek yang alamiah dimana peneliti adalah instrumen kunci, teknik pengumpulan data dilakukan secara triangulasi, analisis data bersifat indukatif, dan hasil penelitian kualitatif lebih menekankan makna dari pada generalisasi. (Sugiyono, 2003).

Teknik pelaksanaan penelitian ini menggunakan teknik survei. Penelitan survei mempunyai ciri - ciri data survei dapat dikumpulkan dari seluruh populasi, atau dapat pula dari hanya sebagian saja dari populasi (Riyanto dalam Agus Surya Wardana 2013).

\section{Penentuan Lokasi dan Sampel}

Lokasi penelitian ditentukan langsung oleh peneliti secara sengaja (purposive sampling) dengan mempertimbangkan aspek tertentu. Lokasi penelitian yaitu di Pasar Anom pada Toko Arif dengan pertimbangan - pertimbangan; Pasar Anom adalah salah satu pasar terbesar di Kabupaten Sumenep; merupakan salah satu pangsa kecap yang ada di Kabupaten Sumenep; Pasar Anom merupakan salah satu pasar yang memiliki banyak konsumen tetap kecap cap Ikan Terbang karena harga yang relatif murah dan produk yang mudah di dapat; Toko Arif menjual produk kecap cap Ikan Terbang; Toko Arif mempunyai konsumen tetap kecap cap Ikan Terbang.

Penentuan sampel di lakukan dengan metode insedental sampling, insidental sampling merupakan metode penentuan sampel yang didasarkan atas kebetulan/insidental. Dalam sampling insidental orang yang bertemu dengan peneliti dapat di gunakan sebagai sampel, bila orang yang kebetulan ditemui cocok sebagai responden dalam pengumpulan data (Sugiono, 2012). 
Jumlah sampel minimal sepuluh kali dari jumlah variabel yang diteliti (Suliyanto, 2005). Variabel penelitian yang diteliti terdapat 5 variabel. Sehingga anggota sampel yaitu $5 \times 10=50$ jadi jumlah sampel yang diambil dalam penelitian yaitu 53 .

\section{Data dan Analisis}

Data Primer diperoleh dengan cara wawancara, observasi dan kuesioner sedangkan data sekunder diperoleh dari studi literatur dan dokumen yang dikeluarkan oleh instansi yang berkaitan dengan penelitian. Responden dalam penelitian adalah konsumen kecap Cap Ikan terbang.

Skala pengukuran adalah skala likert, karena dapat digunakan untuk mengukur sikap dan pendapat seseorang atau sekelompok orang tentang kejadian atau gejala sosial.

Analisis data menggunakan ChiSquare dinyatakan dalam rumus:

$$
X^{2}=\sum_{i=1}^{k}\left[\frac{(f o-f e)^{2}}{f e}\right]
$$

(Sugyono dalam Rochmawati dkk, 2018).

Analisis selanjutnya adalah analisis kontingensi untuk mengukur kuatnya hubungan antara sikap konsumen terhadap pembelian kecap koefisien kontingensi tersebut diberi simbol $C_{c}$ :

$$
C_{c}=\sqrt{\frac{x^{2}}{x^{2}+n}}
$$

Keterangan :

$x^{2}=$ Nilai chi square

$\mathrm{n}=$ Besar sampel

( Purnomo, 2014).

\section{HASIL DAN PEMBAHASAN Gambaran Umum Lokasi Penelitian}

Pasar Anom merupakan salah satu pasar yang sudah berdiri pada masa perkembangan II Kota Sumenep (1987sekarang) dan merupakan salah satu pasar terbesar yang ada di Kota Sumenep. Dimana di dalam pasar tersebut adalah tempat penjual dan pembeli bertemu dan keduanya melakukan transaksi sebagai penjual dan pembeli secara langsung dilokasi. Tempat barang yang dijual berupa kios maupun dasaran yang diizinkan untuk dijadikan tempat jualan oleh petugas atau pengelola pasar. Kebanyakan menjual kebutuhan seharihari seperti sayur-sayuran, ikan, daging, buah, dan bahan-bahan makanan lainnya. Salah satu kios/toko di pasar anom yaitu toko arif yang saat ini menjadi objek penelitian, dimana salah-satu dagangannya yang menjadi objek pembahasan yaitu kecap cap ikan terbang.

\section{Gambaran Umum Produk}

Kecap cap ikan terbang merupakan kecap yang memiliki cita rasa yang khas yang beda dari yang lain dan dapat memenuhi selera konsumen serta harga cukup terjangkau oleh setiap kalangan dengan rasa, merk, kemasan yang ditampilkan jadi ciri khas tersendiri dari kecap cap ikan terbang khas gapura sehingga dapat menjadi daya menarik konsumen. Dimana produk kecap cap ikan terbang mempunyai 2 macam bentuk kemasan dengan harga yang berbeda, yaitu kemasan botol kaca yang mempunyai berat isi $620 \mathrm{ml}$ dengan harga Rp. 14.000,-dan kemasan plastik yang mempunyai berat isi 200gr dengan harga 1500,-.

\section{Karakteristik Responden}

Konsumen merupakan orang yang akan memakaiatau membeli barang maupun jasa yang kepada produsen sebagai penyedia di tengah masyarakat, yang dapat dipergunakan untuk memenuhi keperluan diri sendiri, keperluan keluarga maupunn keperluan orang lain, (Suryani, 2003). Konsumen insidetal adalah 
konsumen siapapun yang secara tidak sengaja (kebetulan) bertemu dengan peneliti pada saat pengambilan data dan dijadikan sebagai sampel responden dengan memperhatikan bahwa orang yang bersangkutan sesuai dengan kriteria konsumen sebagaimana yang telah ditetapkan sebelumnya oleh peneliti sehingga dapat dinyatakan layak sebagai sumber informan dalam pengumpulan data penelitian (Sugiyono, 20015).

Responden merupakan sampel penelitian yang diambil dari suatu populasi sebagai sumber informan dalam pengumpulan data dan responden harus dapat mewakili populasi, oleh karenanya mengetahui lebih dalam tentang responden merupakan bagian penting dari penelitian. Pada penelitian ini ditetapkan responden sebanyak 60 responden. Dalam penelitian yang dilakukan dengan metode analisis chi Tabel 1. Data Rekapitulasi Variabel yang Disukai

\begin{tabular}{|l|l|l|l|l|l|l|}
\hline Indeks Kepuasan & Rasa & Harga & Kemasan & Tempat & Ketahanan & Jumlah \\
\hline S & 24 & 15 & 1 & 0 & 1 & 41 \\
\hline TS & 2 & 1 & 2 & 4 & 3 & 12 \\
\hline Jumlah & 25 & 16 & 3 & 4 & 4 & 53 \\
\hline
\end{tabular}

Sumber : data primer diolah

\section{a. Rasa}

Rasa merupakan salah satu hal yang paling di sukai atau dipertimbangkan dalam membeli suatu barang yang berkaitan dengan masakan atau makanan karena rasa merupakan suatu cara pemilihan konsumen terhadap produk atau makanan yang hanya dapat memiliki nilai rasa maupun pembeda dengan produk lain jika telah dirasa melaui indra pengecap. Hasil wawancara terhadap konsumen kecap cap Ikan Terbang di Pasar Anom bahwa konsumen menyukai rasa atau memilih rasa karena rasa pada produk kecap Cap Ikan Terbang mempunyai rasa yang manis dan gurih dimana sangat cocok untuk masakan atau makanan seperti soto, rawon, rujak dan lainnya.
- square, sampel yang harus digunakan adalah sepuluh kali dari jumlah variabel (Suliyanto, 2005).

Pengukuran di lakukan dengan menggunakan pengukuran interval yaitu pengukur dengan skor atau nilai jawabannya terhadap koesioner dengan semua opsi : Sangat Suka, Suka, Cukup Suka, Tidak Suka, Sangat Tidak Suka. Yang masing-masing kategori di berikan nilai 1 sampai 5.

\section{Variabel Yang Disukai Konsumen}

Dari hasil data rekapitulasi dapat dilihat bahwa konsumen lebih mempertimbangkan pembelian kecap cap Ikan Terbang di Pasar Anom karena rasa dan harga dan untuk pertimbangan selanjutnya pada kemasan, tempat, dan ketahanan. Sebagaimana dapat dilihat dalam penguraian tabel 1 :

\section{b. Harga}

Harga adalah suatu unsur penting dalam bauran pemasaran, tanpa harga produk tidak bisa ditawarkan kepada konsumen. Yang menjadi masalah, harga berapa suatu produk harus ditetapkan. Tidak mudah menetapkan harga suatu produk atau barang, banyak faktor yang perlu diketahui sebelum menetapkan harga suatu produk (Yoeti (2005).

Harga menjadi salah satu yang di sukai atau dipertimbangkan setelah rasa. Hal itu disebabkan harga kecap cap ikan terbang sangat sesuai dengan rasa, bentuk dan ukuran produk seperti yang diinginkan konsumen. Responden juga menyatakan bahwa harga yang telah ditetapkan pada kecap cap ikan terbang tergolong sangat terjangkau yaitu dengan harga kecap Rp. 14.000,- perkemasan 
botol kaca dengan volume isi $620 \mathrm{ml}$ sedangkan kecap kemasan plastik dengan volume isi $200 \mathrm{gr}$ dengan harga $\mathrm{Rp}$. $1.500,-$.

\section{c. Kemasan}

Kemasan berguna sebagai media yang dapat melindungi, membungkus, mempermudah pengiriman, mempermudah dalam mengeluarkan, menyimpan, mengidentifikasi serta dapat dikategorikan sebagai atribut produk yang menjadi pembeda antara suatu produk yang sejenis namun dari merek yang berbeda (Klimchuk dan Krasovec, dalam Wardana 2013). Kemasan adalah bagian selanjutnya yang di sukai atau dipertimbangkan oleh konsumen dalam membeli kecap cap Ikan Terbang yang mana kemasan kecap merupakan bagian pertama produk yang dilihat langsung oleh pembeli dan mampu memberikan daya tarik tersendiri.

Produk kecap cap Ikan Terbang mempunyai kemasan botol kaca dan plastik. Dan sebagian besar konsumen mengatakan bahwa kemasan produk kecap cap Ikan Terbang prkatis dan sisa botol yang telah di pakai dapat ditukarkan dengan botol kemasan baru dengan harga yang sama.

\section{d. Tempat}

Tempat merupakan pilihan berikutnya yang di sukai atau dipertimbangkan oleh konsumen dimana tempat merupakan penjualan produk tersebut dilakukan. Produk kecap yang dipasarkan atau dijual di Pasar Anom tepatnya di Toko Arif dimana toko Arif mempunyai tempat yang strategis karena berada di pinggir jalan dan transportasi mudah di dapat seperti becak.

\section{e. Ketahanan}

Ketahanan menjadi pilihan berikutnya yang di sukai atau dipertimbangkan oleh konsumen dalam membeli kecap cap Ikan Terbang karena ketahanan merupakan mutu dari suatu produk pangan berdasarkan kemampuan atau daya simpan produk yang tidak mudah rusak dalam rentang waktu pada saat produksi hingga sampai di meja konsumen untuk dikonsumsi atau dengan istilah exp dalam kemasan. Konsumen juga memperhatikan exp dalam kemasan karena apabila exp dalam kemasan melebihi batas yang sudah tercantum dalam kemasan maka dapat berpengaruh pada kesehatan. Maka dari itu konsumen juga perlu melihat dan mengetahui exp pada kemasan. Produk kecap cap Ikan Terbang sudah mempunyai exp yang sudah tercantum pada kemasan dan juga sudah tercantum no P-IRT No. 2113529020175-18.

\section{Hubungan Antara Variabel Dengan Kesukaan Konsumen}

Dari hasil analisis chi-square yang telah dilakukan didapat hasil nilai $\mathrm{X}^{2}{ }_{\text {hitung }}$ sebesar 29,11 pada $\alpha=0,05$. Nilai ini dibandingkan dengan $\mathrm{X}^{2}$ tabel yakni sebesar 3,481. Dari perbandingan tersebut terlihat bahwa nilai $\mathrm{X}^{2}$ hitung lebih besar daripada $\mathrm{X}^{2}$ tabel sehingga dapat dinyatakan terdapat hubungan antara kesukaan konsumen terhadap semua variabel kecap cap Ikan Terbang.

Dengan memasukkan nilai chisquare $\left(\mathrm{X}^{2}\right)$ sebesar 29,11 ke dalam rumus koefisien kontingensi $\left(\mathrm{C}_{\mathrm{c}}\right)$ dengan nilai $\mathrm{n}$ sebesar 53 maka akan diperoleh nilai koefisien kontingensi $\left(\mathrm{C}_{\mathrm{c}}\right)$ sebesar 0,59 yang artinya ada hubungan signifikan antara kesukaan konsumen terhadap semua variabel kecap Cap Ikan Terbang yang dapat dilihat dalam lampiran 5. Dari hasil uji skala likert akhir menunjukkan hasil $88,6 \%$ berada dalam kategori "Sangat Suka" yang artinya konsumen sangat suka terhadap produk kecap cap Ikan Terbang di Pasar Anom.

\section{Kesimpulan}

Variabel yang disukai atau yang lebih dipertimbangkan terlebih dahulu 
oleh konsumen yaitu rasa dan harga. Variabel kemasan, tempat dan ketahanan menjadi pilihan variabel selanjutnya yang disukai atau dipertimbangkan oleh konsumen. Terdapat hubungan yang signifikan antara kesukaan konsumen dengan semua variabel penelitian yang meliputi rasa, harga, kemasan, tempat dan ketahanan pada kecap cap ikan terbang yang dijual di Pasar Anom Kabupaten Sumenep. Konsumen menunjukkan tingkat kesukaan "Sangat Suka" yaitu sebesar $88,6 \%$.

\section{Saran}

Produsen kecap cap ikan terbang perlu melakukan survei lebih dalam terkait informasi mengenai atribut agar sesuai dengan kebutuhan konsumen kecap

\section{DAFTAR PUSTAKA}

Rochmawati, F.N., Riyanto, H.W Dan Nuraini, I. 2018. Hubungan Tingkat Pendidikan, Usia, Dan Pengalaman Keja Terhadap Pendapatan Pekerja Wanita Pada Industri Kerajinan Dompet Ida Collection Di Desa Pulo Kecamatan Tempeh
Kabupaten Lumajang. Jurnal Ilmu Ekonomi (2) 3. 399-408.

Sugiyono, 2007. Metodologi Penelitian Kualitatif. Bandun: PT Remaja Roasdakarya.

Suryani. 2003. Perilaku Konsumen. Graha Ilmu: Jakarta.

Suliyanto. 2005. Analisis data dalam Aplikasi Pemasaran. Bogor : Ghaliah Indonesia.

Purnomo, S. 2014. Koefisien Korelasi Cramer Dan Koefisien Korelasi Phi Serta Penerapannya. Skripsi Fakultas Matematika Universitas Negeri Yogyakarta. http://eprints.uny.ac.id/13463/1/SK $\underline{\text { RIPSI.pdf }}$

Wardana, Agus Surya. 2013. Preferensi Konsumen Terhadap Kripik Singkong Mentega Khas Manding Kabupaten Sumenep. Skripsi Fakultas Pertanian, Universitas Wiraraja Sumenep.

Yoeti, Oka A. 2005. Pengantar Ilmu Pariwisata, Angkasa: Jakarta. 